\title{
The Roles of Ulama in the process of Post-Conflict Reconciliation in Aceh
}

\section{Muhammad Sahlan $^{1}$ (D), Suci Fajarni ${ }^{1}$ (D), Siti Ikramatoun 2,* (D, Ade Ikhsan Kamil ${ }^{3}$ (D), and Iromi Ilham ${ }^{3}$}

${ }^{1}$ Department of Sociology of Religion, Faculty of Usuluddin and Philosophy, Ar-Raniry State Islamic University of Banda Aceh, 23111, Aceh Province, Indonesia.

2 Department of Sociology, Faculty of Social and Political Sciences, Syiah Kuala University, 23111, Banda Aceh, Aceh Province, Indonesia.

${ }^{3}$ Department of Anthropology, Faculty of Social and Political Sciences, Malikussaleh University, 24351, Lhokseumawe, Aceh Province, Indonesia.

* Corresponding Author: siti.ikramatoun@unsyiah.ac.id

\section{ARTICLE INFO}

Publication Info:

Research Article

How to cite:

Sahlan, M., Fajarni, S., Ikramatoun, S., Kamil, A. I., $\mathcal{E}$ Ilham, I. (2019). The Roles of Ulama in the process of PostConflict Reconciliation in Aceh. Society, 7(2), 251-267.

DOI : 10.33019/society.v7i2.106

Copyright (C) 2019. Owned by Author(s), published by Society

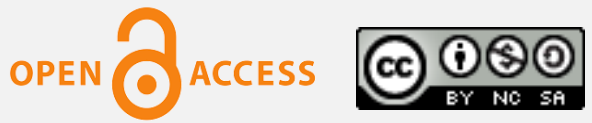

This is an open access article.

\section{ABSTRACT}

In the context of Aceh, the word "Ulama" refers to an Islamic scholar who own boarding school (In Aceh language known as Dayah) or a leader of an Islamic boarding school (known as Teungku Dayah). Ulama become "the backbone" of any social problem and play strategic and influential roles in Acehnese society. However, The Ulama roles have changed in the postconflict era in Aceh. The assumption that Ulama are unable running their authorities in Acehnese society especially in the post-conflict era. Ideally, their roles are needed in the reconciliation regarding the agents of reconciliation who have authority like the Ulama and are trustworthy by Acehnese society. Therefore, this article aims to discuss the position of Ulama in the process of post-conflict reconciliation in Aceh. To investigate the problem, a descriptive qualitative method was used, where the method is to describe the nature of a temporary situation that occurs when the research is carried out in detail, and then the causes of the symptoms were examined. The data were literature studies, participatory observation, and in-depth interviews. The results of this research showed that during an important period of Aceh's history, the Ulama constantly become guardians that provide a religious ethical foundation for each socio-political change in Aceh, and subsequently they also act as the successor to the religious style that developed in the society. Even the formation and development of the sociopolitical and cultural system occurred partly on the

Copyright (C) 2019. Owned by Author(s), published by Society. This is an open access article under CC-BY-NC-SA license. 


\section{License: Attribution- \\ NonCommercial-ShareAlike (CC BY-NC-SA)}

Received: October 31, 2019;

Accepted: December 28, 2019;

Published: December 31, 2019; contribution of the Ulama. The position of Ulama in the process of post-conflict reconciliation in Aceh can be found in four ways. Firstly, knowledge transmission. Secondly, as a legal decision-maker which refers to Sharia law, especially related to the reconciliation process. Thirdly, as a mediator. Fourthly, cultural roles in the form of ritual or ceremonial guides that are carried out when the parties of the conflict have met an agreement to reconcile.

Keywords: Aceh; Conflict; Reconciliation; Sharia; Ulama

\section{Introduction}

"... The Prophet Muhammad (peace be upon him) has said: 'Ulama are the heirs of the prophets'. ... Also, the Prophet Muhammad said: 'The best Kings and the nobles are those who visit the doors of the Ulama, and the worst Ulama are those who visit the doors of the kings and the nobles...'. The Ulama are much superior in dignity and status to others. After them (the Ulama), rank the kings..." (Saletore in Kartodirdjo, 1981: 129)

Saletore has described that the Ulama played important roles in Islamic society during the medieval age. Some studies had discussed the roles and contributions of Ulama in Aceh. Yeoh (1994) examined the relation of Ulama, government, and Acehnese Society which then concluded that Ulama are a quite important group in Aceh. The main point of the role of the Ulama in politics is as the Mufti during the Sultanate of Aceh Darussalam. Then Saby (1995) examined the role of Ulama for the people of Aceh. Saby found that aside from being a Mufti Sultan, Ulama had also served as preachers, educators, and freedom fighters. Some of the famous Ulama names at that time were Syamsuddin al-Sumatrani, Nuruddin al-Raniry, and Abdurrauf al-Singkili, who also served as the justification of the Malikul Qadhi or Supreme Court Judge (Azra, 1998: 202). Some other studies about strengthening post-conflict that relate directly to the Ulama mostly speak to the realm of Islamic Sharia enforcement (see, Ichwan, 2011; Sabil, 2012; Sufyan, 2016; Firdaus, 2019).

In Aceh, Ulama are still the "backbone" of decisions in a variety of issues and they are as strategic and influential groups. Not only related to religious issues, but also as a spiritualbased "medical personnel" who is considered to cure various diseases. Some cases showed that when a family member is sick, the first aid is to bring a bottle of mineral water to the Ulama to be spelled out (in local terms known as ie teurajah) (Ilham \& Abdullah, 2015: 101).

However, the roles of Ulama in Aceh have changed. Some people make assumptions that they are unable to play their roles in society since the power and governance systems have changed especially when Aceh annexed to the Republic of Indonesia. Moreover, the Ulama in Aceh created an institutional system and claimed each other as "the real Ulama" raising a role competition among them (Bustamam-Ahmad \& Amiruddin, 2013: 64). At some level, some parties question the existence of Ulama as actors who actually "create" the conflict itself, or even become part of the conflict that is happening. On the other hand, the Ulama group seemed more focused on ideological issues, and some were involved in the realm of practical politics.

Copyright (C 2019. Owned by Author(s), published by Society. This is an open access article under CC-BY-NC-SA license. 
Bustamam-Ahmad \& Amiruddin (2013: 55-56) explained that the Ulama Aceh was a legitimate group through traditional and charismatic authority. With charismatic authority, Ulama in Aceh have great potential in managing and manipulating the social life of the Acehnese society, including in the case of post-conflict reconciliation in Aceh (1976-2005).

After the signing of the MoU in Helsinki, Aceh entered a new phase after a long conflict. Efforts to reconcile post-conflict continue to be pursued by various parties, including by the government. The Aceh Truth and Reconciliation Commission (Aceh TRC, Indonesian: Komisi Kebenaran dan Rekonsiliasi Aceh or KKR Aceh) which was ratified through Qanun Number 17 of 2013 provides hope for strengthening peace in Aceh. The Aceh TRC is expected to be able to open truth spaces and contribute to the enforcement of human rights in Aceh specifically. However, since the institution officially operated on October 24, 2016, the efforts to reconcile victims of conflict are unclear.

Through the Aceh TRC, efforts at reconciliation continue to have endeavored so that the conflict that had occurred did not recur. The concept of reconciliation in this case according to the Aceh Qanun Number 17 of 2013 concerning the Aceh Truth and Reconciliation Commission, is interpreted as the result of a process of disclosing the truth, recognition, forgiveness, and reacceptance of victims and perpetrators by the Acehnese society. This means that reconciliation is expected to be a unifying bridge, to achieve justice and peace on the Mecca's verandah.

The position of Ulama as a strategic group should ideally take the maximum role in the reconciliation process, considering that there is currently no reconciliation agent that has authority like the Ulama and is truly trustworthy by the people of Aceh. The presence of Civil Society Organizations (CSOs) or institutions formed by the State in the reconciliation process is often seen by the Acehnese society as not independent, especially by victims and conflict parties. For this reason, this research aims to discuss the position of Acehnese Ulama during the conflict and post-conflict period, especially in terms of reconciliation.

\section{Literature Review}

Historical records about the social dynamics of various dimensions in Aceh have involved Ulama. However, post-peace, the roles of Ulama have shifted and changed. Several studies noted that Ulama in Aceh are an important element among Acehnese society until today, they still have a source of legitimacy to influence the people (see, Saby, 1995, 2001; BustamamAhmad \& Amiruddin, 2013; Ilham \& Abdullah, 2015; Firdaus, 2019). But, nowadays, the charismatic Ulama in Aceh have rarely involved as mediators or reconcilers. Even in other social domains, Ulama still exists and be the source, but in the case of post-conflict reconciliation, the involvement of Ulama "seems" almost difficult to detect. There are no works of literature on post-conflict reconciliation in Aceh that specifically study charismatic Ulama as agents of reconciliation. Whereas sociologically, Ulama in Aceh have a strategic position to play their roles.

The literature on Ulama in Aceh is now very abundant. Several works of academics and scholars discussed the existence of Ulama in Aceh. The literature commonly discussed the roles of Ulama related to religious, developmental, social, economic, political and triumphant aspects of the past. It is still difficult to find studies related to the role of the Ulama in reconciliation.

Saby (2001) specifically discussed the position of Ulama in Aceh in the span of history. This included studies relating to the political role of several Ulama leaders in Aceh. Since the coming of Islam into the Malay-Indonesian archipelago, Ulama have played a major role. The mastery of Islamic knowledge places Ulama as members of the social elite in society. Society

Copyright (C 2019. Owned by Author(s), published by Society. This is an open access article under CC-BY-NC-SA license.

https://doi.org/10.33019/society.v7i2.106

253 
views the Ulama as a place to ask for guidance, and on the other hand, the authorities use it as a source of legitimacy.

Firdaus (2019) also noted the same thing. Organizationally the Ulama in Aceh had played a role since the Ulama established the All-Aceh Religious Scholars' Association (Indonesian: Persatuan Ulama Seluruh Aceh or PUSA) in 1939. Then after the PUSA broke up, in the New Order era, the Ulama in Aceh established the Ulama Consultative Council (Indonesian: Majelis Permusyarawatan Ulama or MPU) in 1965 which later became a forum for the Ulama for deliberation, issuing fatwa and giving advice to the government.

In the broader context of conflict, according to Ibrahim (2003: 31), religion is a variable that must be taken into account when looking at conflicts in Aceh. With a very high sensitivity to religion, religion can be used as a support and even gain support on a broader scale. Religion has even been a factor in the ongoing conflict in Aceh for a very long time. This can be seen in the war that raged in Aceh when the Ulama beat the drums of war against the colonial Dutch East Indies. The spirit of resistance had once made the Dutch confused with the courage and desperation of the people. The Acehnese at that time fought not to win but to get shaheed and heaven (Ibrahim, 2003: 31).

During the Darul Islam/Indonesian Islamic Armed Forces (Indonesian: Darul Islam/Tentara Islam Indonesia or DI/TII) local elites who waged resistance to the Indonesian government also came from the Ulama and Ulama representatives. At that time, Ulama and religion are still the variables of the strengthening of popular resistance and great support for the establishment of DI/TII. Different things happened in the 1970s conflict period which Ibrahim (2003: 32) referred to as a period of contemporary conflict where religion tends to be used more as a symbolic move as a justification or value base for the activities of struggle carried out. During this period the escalation of violence tended to increase significantly. Further, religious symbols, according to Ibrahim (2003: 33) became the best language to translate the reality that occurred during the escalation of violence that took place quite high. As on several occasions, the security forces often read the Badr prayer at the time of the troops before carrying out security operations.

Also, many other symbols as summarized by Ibrahim (2003: 33), namely the writing of Allahu Akbar (Allah is the Greatest) and Bismillahirrahmanirrahim (In the Name of Allah, the AllMerciful and Most Merciful) on the walls of trucks and other military vehicles. This phenomenon was translated by him as a form of legitimacy and provided a clear boundary that the security operations carried out by the government of the Republic of Indonesia were on the religiously correct track and the other hand wanted to obscure the propaganda of Aceh's ideals in the effort to be independent.

The same pattern is also shown by the Free Aceh Movement (Indonesian: Gerakan Aceh Merdeka or GAM) which seeks to provide stimulation to the people of Aceh that the movement which is fought for is not immune from religious teachings. Or in other words, it gives legitimacy that the Free Aceh Movement is a successor movement that represents the predecessor movement which has also fought 'enemies'; 'enemies' defined as infidels or 'enemies' who have broken political promises.

Although Ibrahim (2003: 34) mentioned various labeling as symbolization and even manipulation of symbols, it cannot be translated as a common (generalization) that each warring group utilizes religion as a symbol of struggle. When viewed from the process of habituating the recitation of Surah Yasin on the day leading up to the 4th December, Azan (call to prayer) took part in the conduct of the flag ceremony and prayed at the mosque for the success and achievement of the ideals of the Free Aceh Movement, because the habituation was

Copyright (C 2019. Owned by Author(s), published by Society. This is an open access article under CC-BY-NC-SA license.

https://doi.org/10.33019/society.v7i2.106

254 
not done occasionally, but had become routine for the Acehnese society. Aceh and Indonesia, in general, are incidentally the largest Muslim society in Southeast Asia. Moreover, Aceh is upholding Islamic values through daily routines such as recitation and mosques as the epicenter of activities.

Although it cannot be denied that the embodiment of language and religious activities can be interpreted from a symbolic perspective. If interpreted arbitrarily, this understanding can be seen from how the groups that conflict interpret the religious spirit that they made themselves. So that when denial is present the religious symbolization which is used as one of the strategies to gain support can be accepted as concluded by Ibrahim (2003: 34).

\section{Research Methodology}

This research was qualitative descriptive. According to Neuman, descriptive research is:

"Research presents a picture of the specific details of the situation, social setting, or relationship. The outcome of a descriptive study is a detailed picture of the subject". (Neuman, 2000: 64)

This research was to describe the nature of a temporary situation that occurred during the research was conducted and was to examine the causes of the symptoms. By using this approach, the position of Ulama in post-conflict reconciliation was explored. This is possible because the researcher automatically places the object of research as an active subject in a natural environment and is attempted to be described reciprocally (Koentjoroningrat, 1991: 87; Faisal, 1989: 18; Ferdiansyah, 2015: 6).

This research was carried out in Aceh Besar Regency and Pidie Regency, Aceh Province, Indonesia, due to the places that were considered as representative to explain and understand the potential, position, and role of the Ulama in terms of reconciliation. Besides, the choice of location also considered for the following reasons; firstly, the Pidie area was the largest conflict base area in the period 1976-2005 that the intensity of the conflict and the number of victims also was quite large. Secondly, reconciliation is one of the goals of the peacebuilding itself.

The stages of Data Collection and Data Analysis in this research consisted of several stages, namely;

1) Literature Study. Data and information were obtained from reputable journals, books, legislation, newspapers, articles, and documents that supported the research process and analysis of the research problems.

2) Participatory Observation. This stage became the initial instrument that was useful to obtain key events to add more detailed and real narrative research reports based on facts in the field.

3) In-depth Interview. The main purpose of this stage was to prioritize personal interaction with the participants. This process was conducted by inviting the key participants that have specialized knowledge on the map of the Ulama and the social network that was built as well as the specific roles that are carried out in peacebuilding efforts through reconciliation.

After data has been collected, the next step was to inductively analyze to build patterns, categorized and their themes from the bottom up, and then process the data into more abstract information units to produce a complex picture of a problem or the issue under study (Creswell, 2010: 261-263). To maintain the validity and reliability of the data, the overall data was combined which was obtained from the data collection techniques described above. 


\section{Results and Discussion}

In the context of Indonesia, there may be absolute confidence that in the several historical studies of Aceh have constantly verified the significant roles of Ulama. Several works of literature stated that the formation \& development of the socio-political and cultural among the society took place partly at the contributions of the Ulama. Even in every essential duration of the history of Aceh, the Ulama continually seemed like a pressure that gives a religious ethical foundation for each socio-political change, and eventually acts as a successor to the religious style that develops in Acehnese society (Saby, 2001: 1).

\section{A. Ulama Aceh Throughout The History}

Aceh and Islam are like an inseparable side of the coin. Almost all Acehnese agree that being an Acehnese is inseparable from being a Muslim since the identity of Aceh and Islam has deep historical roots. Aceh's location on the northwestern tip of Sumatra that makes it the first point of contact for Arab and Indian traders visiting the archipelago. It is widely known that the oldest Islamic kingdom in Southeast Asia was in Aceh, precisely in the Pasai area (near Lhokseumawe). For centuries, Aceh was not only an important military force but also the center of Islamic learning and trade (Aspinall, 2007: 248).

Based on the historical sources, both from the records of European explorers or Acehnese traditions such as the Hikayat Raja-Pasai (the story of Pasai King) and Malay History, the Ulama have made an important contribution in the development of the Samudra Pasai Kingdom to become the leading Islamic empire in the 13th Century in Archipelago. The contribution has been credited with making Samudra Pasai kingdom as the basis for the process of Islamization in the Malay world, and Aceh in particular (Saby, 2001: 2).

Sultan Iskandar Muda (1607-1636) was the well-known sultan for his continuous attacks on the Portuguese in the Malacca Strait with Islam as the basis for his ideological struggle (Hadi, 2004: 30). During the next two centuries, the economic power of the Dutch experienced a setback, while the Islamic awareness of the people of Aceh increased significantly, mainly through the teachings of the Ulama such as al-Raniry and al-Singkili. In 1824, along with the Anglo-Dutch agreement, Aceh was in a precarious position because of its sovereignty which had been recognized by Europe, but at the same time, the island of Sumatra was claimed by the Dutch. Then the Dutch attacked Aceh in 1873 and at the same time became the biggest military attack in Dutch history. During 40 years of fighting against Aceh, the leadership of the Aceh guerrilla forces against the Dutch shifted to the hands of the Ulama within the framework of the Holy War, which was coordinated from mosque to mosque and every Friday sermon. The Ulama of that era wrote the tale of the Sabil war (the Holy War), which stated that resistance to drive out the Dutch was an obligation for all Muslims and declared it a jihad (Siegel in Aspinall, 2007: 249). The leadership of the Ulama in the Dutch war lasted for 60 years. Within this time the Ulama had confirmed their presence in Acehnese politics and society.

It is undoubtedly that Ulama had a vital role in the period. The position and role of Acehnese Ulama became greater when the kingdom reached its golden age in the 17th century. During this century, the kingdom of Aceh became the center of the birth of prominent Ulama around the archipelago, such as Hamzah Fansuri, Syamsuddin al-Sumatrani, Nuruddin alRaniry, and Abdurrauf al-Singkili. Through their intellectual works, encourage the development of intellectual traditions and religious thoughts. Even, the Ulama in the Aceh kingdom also sat in important positions in the royal structure such as the position of Shaykh alIslam, which was a level below the Sultan. Through these institutions, the Ulama became the

Copyright (C 2019. Owned by Author(s), published by Society. This is an open access article under CC-BY-NC-SA license.

https://doi.org/10.33019/society.v7i2.106

256 
king's companion who helped determine every important and strategic decision in the kingdom.

Not only the political role of the Ulama was even more prominent in the later period, but also when the people fought against the Dutch colonialism. The Ulama became the foundation of the ideology of struggle, which was formulated in the concept of jihad (war in the way of Allah with the reward of heaven). This holy war was carried out not to defend Aceh, but against those who commit crimes. In this context, the Ulama not only supports but also provide an ideological-religious foundation. The Ulama took on the role of formulating and giving meaning to the struggle of the people against Dutch colonialism. This position continued until it entered the beginning of the 20th century. When modernization began to enter the lives of the people of Aceh, the Ulama acted as agents of Islamic renewal. Through the All-Aceh Religious Scholars' Association (PUSA), an institution founded in 1938, the Ulama fought for the empowerment and development of Aceh's Muslims. The PUSA officially aims to develop a modern Islamic education system in Aceh with a vision not to return to Aceh's "golden age", but to welcome a "glorious future", where all Muslims will unite through religious law (Morris in Aspinall, 2007: 250). In its first public statement, the PUSA organization said:

"...to proclaim, uphold and defend the greatness of the holy Islamic religion, especially in the land of Aceh, which had bestowed upon it the name of 'Mecca's verandah' in its past golden age, but which for some time now has become a country left far behind by its near neighbors, let alone those more distant, and which has for so long remained in the valley of unbelief and darkness". (Aspinall, 2007: 250)

Daud Beureueh, a charismatic Ulama and a leader of PUSA has combined Islamic teachings with anti-nationalism, colonialists and Western organizations. PUSA opposed Dutch colonialism, received Japanese assistance, and was able to defeat the Dutch before the arrival of aid from Japan. After World War II, Beureueh and the Ulama carried out a social revolution and established political hegemony. After the proclamation of independence in 1945, under the leadership of the Ulama, Aceh was the only area in Indonesia that did not fall back to the Dutch. Even the Acehnese forces struggled to support the Republic of Indonesia within the framework of jihad (Barter, 2008: 14).

After the war for independence, Aceh entered a new phase, a period of conflict that began when Aceh was fused with northern Sumatra, which then ignited Ulama resistance against the Republic of Indonesia. This conflict was gradually resolved through a series of negotiations in the 1960s, with Aceh regaining the status of its province and autonomy to implement Sharia law.

However, over time the influence of the Ulama has gradually declined, especially, when the Free Aceh Movement (GAM) demanded independence from the Indonesian government, starting in 1976. During this time the role of the Ulama declined when the new order government under the command of President Soeharto (1967-1998) tried to co-opt the support of the Ulama on one side and GAM demanded their loyalty on the other side. However, after the Aceh tsunami in 2004, the government and GAM negotiated a peace agreement through the Helsinki MoU in 2005, Ulama in Aceh re-emerged and played a more significant role.

During the GAM era conflict (1976-2005), it was generally agreed, though rarely explained, that the current conflict lacked a religious dimension. If anything, religious organizations in Aceh support the state, Ulama in the MPU were even asked by the Indonesian state to pressure GAM during peace negotiations. As a result, GAM saw the Ulama as a tool for the state's 
agenda (Kingsbury, 2006: 188). Meanwhile, GAM leaders only spoke to Western countries and developed an ethnic nationalism (ethnonationalism) discourse that was partly cleansed from Islamic elements. Based in Sweden, GAM leaders initially spoke about socialism and anticolonialism then shifted the human rights framework to legitimize independence.

In the early of the New Order, President Soeharto with economic development had weakened Ulama in Aceh. Even during the GAM conflict, most of the Ulama's role was somewhere between neutral and pro-state, except those in GAM's base area. At this time Barter (2008: 16) states that Pro-Indonesian Ulama can be separated into two categories, namely career Ulama (who earn a living through state organizations) and Dayah Ulama (active teachers). The first category is the Ulama who support the state. According to Barter (2008: 16-17), the career of Ulama included state-sponsored legislative officials, universities, political bodies, and Ulama Organizations. The Indonesian authorities often called on the Ulama to support government policy and speak out against GAM. In line with this, Mukhlisuddin Ilyas (respondent) said:

"Before the conflict, Ulama's position in Aceh was only as a follower, as a supporter, and provider of wise advice or social justification. During the New Order era, many Ulama were used as 'spokesmen', and the reform period of the Dayah Ulama was only a counterweight". (Interview, July 2019)

During this period the power of the Ulama began to weaken due to its involvement in the practical politics of the period. Most of the Ulama were incorporated into political parties (PPP: United Development Party, or Development Unity) and several institutions were formed during the New Order (MPU: Ulama Consultative Assembly) (Barter, 2008: 14). In other words, Ulama are only positioned as parties outside the framework of the ongoing conflict in Aceh.

Besides, the position of Ulama is also weak due to internal reasons such as the decreased interest of the Acehnese society in schools run by traditional Islamic educational institutions (Dayah) due to losing competition with state-run Madrasas. Another problem is the result of decades of conflict, teaching new generations to be ignored, new "Ulama" failing to be reproduced. Meanwhile, new secular elites produced by the University of Aceh continue to emerge, as well as Soeharto's Golkar Party control in the provincial bureaucracy that dominates Aceh's economy. The weakening of the authority of the Ulama continued until the signing of the Helsinki MoU in 2005 (Barter, 2008: 16).

The position of the Ulama which is considered ambiguous and paradoxical when compared to its role in the war against the Dutch and the DI/TII Movement not only caused disappointment, doubt, and insults in the Acehnese society. This causes the emergence of hadih maja, who identified the Ulama, who could be used as central figures and not, in solving problems that were being faced by the Acehnese society such as their hopes for the story of heroism, courage, and intelligence of previous Ulama. It is this misunderstanding of the adaptation strategy of the Ulama's co-optation efforts that later led to the emergence of a negative maja in Acehnese society when evaluating the Ulama. The maja was read: "Ulama jameun pijuet-pijuet karena le geu kaluet ngen geumeudo'a, Ulama Jinoe Tumbon-tumbon karena sereng jak ek treun rinyeun istana"1 (Amiruddin, 2003:58).

1 Literary, the sayings can be translated as in the past time, Ulama were thin (thin is associated with poor condition) due to they prayed continuously day and night, it different from the today`s Ulama, they are fat (fat is associated with wealthy condition) due to they are friends of power.

Copyright (C 2019. Owned by Author(s), published by Society. This is an open access article under CC-BY-NC-SA license. https://doi.org/10.33019/society.v7i2.106

258 
Although it is recognized that during the conflict the position of the Ulama weakened, it did not mean that the Ulama group was absent from the social dynamics that took place in Aceh. Abidin Nurdin (Acehnese Sociologist) said that Ulama as an institution are always present in the people of Aceh. The role of the Ulama has not changed, only not as significant as in the past. Dayah remained, santri (students) activities with the Ulama also continued. He further said:

"Ulama have not changed, only transformed the roles. In the past, when we referred them to past time, automatically we saw them as persons. Today we see institutions that represent them as Ulama". (Interview, July 2019)

\section{B. The Legitimacy Basis of Ulama in Aceh}

"Abu Tanoh Mirah, everyone respected him, almost 90 percent of people charitable. His charisma arises because of his honesty". (Interview with Teungku Yusri Ahmad, August 2019).

The above interview excerpts stated that the Ulama were legitimized because of personal quality. However, if traced far backward, the legitimacy of the Ulama has taken root.

Dayah is one of the social institutions that are often seen as the epicenter of Aceh's culture. Amiruddin (2017: 4) revealed that Dayah was the guardian of Religion in Acehnese society. According to him, Dayah with its Ulama in Acehnese society remained more glorified than the Ulama who studied in addition to Dayah such as in madrasa (a college for Islamic instruction) and other religious institutions. According to Burhanuddin (2012: 91), Dayah in Aceh has a very large role in providing the enlightenment needed by the people where the Dayah is located. The contribution made is not only in the form of teaching Islam by Dayah Ulama, but it also guides the community in practicing Islamic symbols in daily life.

Aceh had three big Dayah when Hurgronje visited Aceh in the 19th century. The Dayah was located inland, namely Dayah Tanoh Abe, Dayah Tiro, and Dayah Baru Karang. The three became the epicenter of Aceh civilization, through their highly respected and respected Ulama. Not only through the teaching of Islam, but also on organizational power which quickly gave overall dominance and legitimacy throughout Aceh. So that Dayah with the Ulama as the sole representation has influenced the Acehnese society in practice and knowledge, and forms social and economic norms based on Islamic theology (Burhanuddin, 2012: 91). As written by Hurgronje (in Burhanuddin, 2012: 93) that the Islamic symbols have been embedded quite deeply in economic practice, for the Acehnese "agriculture is the king of all livelihoods, so that there is often the appearance of maja: "Pang ulee ibadat, pang ulee hareukat meugo", meaning "The main worship is prayer, look for the main fortune is farming (rice fields)". The religious and economic juxtaposition that is considered the most important in the lives of the people is seen during the marking process of the emergence of three stars which are considered as markers towards Mecca which is interpreted as the time of the start of rice planting. The Dayah Ulama are believed to have the spiritual power to bring blessings or curses, provide healing and sickness and have formulas for a variety of life goals, and the habits of daily life make Ulama have power over every word that is spoken" (Burhanuddin, 2012: 92).

More precisely, the Dayah community is mechanical because the values adopted are singular, prioritizing feelings and have high solidarity. In that community, people who are 
bound by the religious spirit and teungku dayah who are leaders occupy a special position and are highly respected. In this Dayah context, religious structure and social structure together become a unity that ultimately forms the social relations of society (Nirzalin, 2018: 188).

Ulama or commonly called Teungku Dayah as a figure in society has a very important role in creating social order through the formation of norms of shared life which are derived from the Quran, Hadith and also the books of Sufism taught by the Ulama in the Dayah (Nirzalin, 2018: 189). In the realm of intertwined social relations, the transformation of norms of social relations of Teungku Dayah and students that are intensive encourages the emergence of the ideology of "Abstinence against Guree" (abstinence against teachers/teungku) in Dayah. Empirically, this ideology gave emergence to the spirit of fear (obedience) of students without question and in its development became one of the basis of the legitimacy of Ulama and this not only had an impact on students but also the wider community. This happened because basically the gait of Teungku Dayah which had been rooted in cross history made a network of norms that were built into the habitus of the people of Aceh.

The strong gait of Aceh in the lives of the people of Aceh makes the legitimacy of the Ulama in the community stronger. The scientific network that is spread throughout Acehnese society through learning in the dayah and its alumni makes the existence of the Ulama even stronger, especially when the Aceh conflict is over. The momentum of peace provides a large space for Ulama in Aceh to play a bigger role; enforcement of Sharia law for example. Even according to the respondent, Mukhlisuddin Ilyas: "Large groups that today have the potential to become adhesives are Dayah people (Ulama)". Furthermore, related to the basis of Ulama's legitimacy, a Pidie community leader said in an interview that "the Ulama were close to the community so the community respected him very much". In line with that, Otto Nur Abdullah (respondent) said:

"In Aceh, the most respected Ulama were Teungku Imum or Teungku Menasah (mosque imam) because they were the closest to the Acehnese society, and at that time of conflict, they were also the most victimized". (Interview, July 2019)

\section{The Position of Ulama in the Reconciliation of Aceh \\ "Adat bak Poteumeuruhom, hukom bak Syiah Kuala" \\ (Adat (Customary Law) is implemented by the King, the Sharia Law is implemented by the Ulama)}

\section{"Adat ngeun hukom lagee zet ngeun sifeut"}

(Adat and law is like flesh and soul)

The first phrase above aims to emphasize that the issue of adat (customary law) is in the power of the king, while Sharia law is the realm of the Ulama. The second hadih maja intends to explain that the position of customary law in Aceh cannot be separated from Sharia Law. Thus, the customary law that applies in Aceh are derived or adopted from Sharia law. All of this is recognized by the constitutional law as stipulated in the Law of the Republic of Indonesia No. 44 of 1999 concerning Administration of Special Privileges of the Province of Aceh and the Law of the Republic of Indonesia No. 18 of 2001 concerning Special Autonomy for the Province of Nanggroe Aceh Darussalam concerning the implementation of Sharia in the areas of Akidah (Faith), Worship, and Sharia. This condition makes Aceh as one of the provinces that have special autonomy rights to implement the law based on the Sharia concept following its existence (Muhammad, 2003: xiii). 
Therefore, there is always a story about the Ulama in each sheet of Aceh's history, of course with the various roles played. During the kingdom, Ulama were brought to the palace as advisors to the king and muftis for religious and social matters. Since the establishment of the Islamic kingdom in Pasai, this pattern has been practiced. Even Malik Al Shaleh, as the founder of the Pasai kingdom, once asked to bring the Ulama from Mecca and several other places to teach Islam to the people in Pasai. Then, when Iskandar Muda ruled the Islamic Kingdom of Aceh Darussalam (1607-1636), an Ulama titled Islamic Shaykh, Shaykh Syamsuddin AsSumatrani, also became an advisor as well as a royal mufti. As an advisor to the king, the existence of the Ulama was not far from the palace circle. However, the Ulama were not bound by political contracts and therefore could also be a bridge between the people and leaders in expressing their aspirations (Amiruddin, 2008). In this case, there may be a shift, at which time the Ulama are included in the practical level of politics.

According to Bustamam-Ahmad \& Amiruddin (2013: 56), the role of the Ulama experienced a shift in terms of the holiness of the Acehnese society after the MoU in Helsinki. This could be because the Ulama were not able to play the authority like Aceh in the kingdom. This condition is an implication of changes in the system of power and governance since Aceh joined the Unitary State of the Republic of Indonesia. Secondly, there is institutionalization that occurs among the Ulama themselves, such as HUDA (Association of Acehnese Dayah Ulama), MPU (Ulama Consultative Council), and MUNA (Nanggroe Aceh Ulama Council), so that each of these institutions claims to be a group that should be called "Ulama". Third, there is a contestation on the role of Ulama in Aceh. However, this shift does not necessarily eliminate the Ulama as the center of public figures in the social fabric of the people of Aceh.

However, the Ulama as one of the social agents still have the potential to reconcile. As in Weatherbee's terms, the Ulama as personal can be categorized as non-state actors. But institutionally, the Ulama are included in state-actors. Concerning the reconciliation process that took place in Aceh, Abidin Nurdin, a Sociologist in one interview argued as follows:

"The MPU on behalf of the institution that houses the Ulama have the power that can influence government policies in Aceh. The dynamics of our constitution requires Ulama to take part in the development of the State, for example when a problem occurs, then the MPU issues a fatwa, it will be able to influence the government. In the Law on the Government of Aceh (LoGA) it is also regulated. In the policy process and the Aceh government, the cleric has the right to give consideration, whether in the form of tausiyah (da'wah), fatwa or whatever it is". (Interview, July 2019)

Not only being an advisor but also several other roles played by Ulama which in this case are also related to the role of reconciliation over conflicts that occur in the Acehnese society. Based on interviews conducted by this research to several respondents (academics, practitioners, and Ulama) it can be concluded that some of the roles of Ulama in reconciliation, both pre-Helsinki, until the time of peace is present on bumi serambi Mekkah (Mecca's verandah) as follows:

\section{1) The Knowledge Transmission}

The word "Ulama" means "one who knows". From this understanding, we can guess, that the Ulama is a repository of knowledge. The science that is loaded with Islamic values about conflict prevention and conflict resolution based on Islamic values. Ulama can explain all differences from religious perspectives, which are sometimes the roots of conflict.

Copyright (C 2019. Owned by Author(s), published by Society. This is an open access article under CC-BY-NC-SA license. https://doi.org/10.33019/society.v7i2.106

261 
Regarding the function of transmitting knowledge, Mukhlisuddin Ilyas in an interview confirmed that the Acehnese Ulama or "Dayah people" with the concept of "beut seumeubeut" (amaliah and taklim) as a form of knowledge transmission that has been practiced so far has made Dayah able to survive and succeed in building social networks that grew up in Aceh today. Mukhlisuddin Ilyas said:

"The largest social structure of the people today is the Dayah people, and those who have the largest mass in Aceh are the Dayahs. Now, the Dayah people are at the level of influence rather than be the level of influenced". (Interview, July 2019)

The interview excerpt emphasized that the current reconciliation process would be influenced by Ulama. If not in a practical form, then in other forms such as providing a roadmap related to reconciliation based on Sharia and values that live in Acehnese society. The same thing was also emphasized by Abidin Nurdin:

"The contribution of the Ulama was in the form of thought. The Ulama contribute in the context of how victims of the conflict have their rights. For example, diyat (fine or compensation), which is now used by the Aceh government". (Interview, July 2019)

As another example, when Aceh was still in a period of conflict, we could explore how the Ulama played a role in unhealthy political and social dynamics. The Ulama must still have the courage to convey the amar ma'ruf nahi mungkar (do good deeds and abandon bad ones) even though sometimes it clashes with the interests of the authorities or the interests of the warring parties (Ilham \& Abdullah, 2015). Likewise during the referendum issue in Aceh in 1999. There were around 500 Dayah Ulama gathered at the tomb of Syiah Kuala, Banda Aceh to discuss their attitude towards Aceh's political situation at that time. This meeting, resulting in some fatwa, for example, may not kill, may not intimidate, may not plunder the property of others, and may not commit acts that violate human rights. A decision that is no less important as a result of the deliberation is to support the referendum in Aceh. The meeting took place on September 13-14, 1999. The meeting presidium at the meeting was Tengku H. Nuruzzahri Yahya (Chairman), Tengku H. Syamaun Risyad (Secretary), Tengku H. M. Daud, Tengku H. Saifuddin Ilyas, and Tengku H. Abdul Manan (Bardan, 2008).

After the 1999 referendum issue, the Indonesian government issued the Special Autonomy Law number 18 of 2001 in response to the Aceh conflict. There are some requests from the people of Aceh that are not accommodated by the central government so that the law must be issued. In discussing the draft law, the Ulama were involved. Not only that, Ulama were also involved in the Public Hearing Meeting (Indonesian: Rapat Dengar Pendapat Umum or RDPU) to formulate what should be accommodated in the special autonomy law. The Ulama who were actively involved at that time were Abu Daud Zamzami, Muslim Ibrahim, Tengku Ismaik Yakob, and Tengku Sofyan Shaleh. The special autonomy law then also became the constitutional basis for the implementation of Sharia in Aceh (Bardan, 2008).

Ulama also can choose and sort out what must be done at critical times, for example, the attitude taken by Abu Daud Zamzami during the turbulent referendum issue. Abu Daud, at that time, served as chairman of Inshafuddin (an association for Dayahs and their Ulama), disagreed with the referendum for fear of bringing division among the Ulama. But he still called for conflict cases in Aceh to be resolved peacefully, not by force (Bardan, 2008). 
During the period of Daerah Operasi Militer/DOM (Military Operation Area), the Indonesian military also approached Acehnese Ulama to garner ideological support. The TNI approached Tengku Ali Usman Kuta Krueng and Tengku H. Ibrahim Bardan, leader of the Dayah of Malikussaleh Panton Labu. Then Inshafuddin held a mubahasah working meeting on the 23rd to 26th April 1997. The important decision of the mubahasah: acts that are against, oppose, and committing treason to the legitimate government is haram (illegal). The same law also applies to those who provide assistance and support to those acts (Sulaiman, 2000: 87-88).

\section{2) Legal Decision-Making Related to Islamic Law}

In Islamic teachings, the study of Fiqh (jurisprudence) is divided into four; 1) figh of worship; which is related to Allah; 2) muamalah figh; related to social transactions; 3) figh munakahat; about marriage and the concept of marriage; and 4) jinayat figh; relating to qishas, murder laws, conflict resolution, and others. In this case, the Ulama play a role in providing religious views related to reconciliation for the disputing parties. Mastur Yahya (respondent), in an interview, explained that in the formulation of the reconciliation model to be carried out by the KKR-Aceh (the Aceh Truth and Reconciliation Commission) involving the Ulama, the reparations model which was then taken by the current government identical to Sharia such as di'iet (diyat or fine/compensation), suloh (islah or reconciliation). Likewise, local government regulations in the form of Qanun in their formulation must involve Ulama. Abidin Nurdin (Acehnese Sociologist) stated that through the MPU (Ulama Consultative Council), the Ulama of Aceh played a role through its fatwa. He further said:

"Ulama contribute more to the realm of religion, but if we speak in the context of Aceh or Sharia then it will affect all aspects because Sharia has been understood to be holistic. When we say religion, politics cannot be eliminated there. In the House of Representatives (DPR), there is a general meeting and the meeting cannot be continued when the Ulama are absent and can be canceled because most of the Qanun in Aceh require the presence of the Ulama there ..." (Interview, July 2019).

\section{3) Ulama as a Mediator}

"When President Susilo Bambang Yudhoyono went to Aceh, he immediately visited Abu Kuta Krueng because he was involved in formulating peace which was initiated by the President. Before the Mou dialogue process in Helsinki, there was a process that took place and at that time the Ulama were involved, so it was clear they were involved in the reconciliation process" (Interview with Abidin Nurdin, July 2019).

Mediators are people who understand how to communicate and understand the substance delivered. In the Aceh context, Ulama as mediators of conflicting parties have often been practiced. For example, conflict resolution that ends in murder, then one of them acts as a facilitator, negotiator, and mediator, one of whom is a popular local Ulama called Teungku Meunasah. (Kasim \& Nurdin, 2015: 129). In another context, Abidin Nurdin said:
"The role of post-conflict Ulama is very strong, especially in the context of giving diyat funds for victims of conflict. At that time the government asked for clarity of status, diyat was there in the context of Sharia and it was given an explanation by the Ulama that giving funds for victims of conflict, if, in legal language, there is a legal standing in Sharia. So until now, diyat funds provided by the state for victims of

Copyright (C 2019. Owned by Author(s), published by Society. This is an open access article under CC-BY-NC-SA license.

https://doi.org/10.33019/society.v7i2.106

263 
conflict, there is no rejection from the Acehnese society, and according to Sharia and customary law, there is the practice in Acehnese society" (Interview, July 2019).

Ulama with wisdom and high religious knowledge possessed can play a role in this realm. The persuasive approach is the way the Ulama resolve conflicts in Aceh. These humanist methods are more effective than using violence or militaristic methods in resolving the Aceh case. Reconciliation will occur if the communication can be built effectively by the agent/actor who is the mediator to find a bright spot.

This is what Acehnese Ulama with its authority has been able to become a mediator in various events using cultural approaches such as suloh, peumat jaroe, damee, and peusijuek. Arief (respondent) said:

"In the prevailing damee method, the popular term "saboh pisang taplah dua" means that if there are a dispute and the dispute results in the loss of one party, then the loss will be borne together" (Interview, September 2019).

\section{4) The Cultural Roles}

The cultural role referred to here is ceremonial, celebrations or rituals carried out if the warring parties have found an agreement to make peace. If the conflicting parties have given up on the case, peusijuk will be held (the process or ritual of sprinkling the flour of the disputing parties, especially the victims), peumat jaroe (a peace process with a symbol of shaking hands and forgiving one another until the loss of revenge), khanduri (thanksgiving for peace and at the same time an expression of pleasure for establishing peace). All of these activities involve Ulama and at the same time place the Ulama as the main actor of the ritual performed, although at certain levels it is also sufficient to be carried out by traditional leaders.

\section{Conclusions}

In each important period of Aceh's history, the Ulama always appear as a unity that gives an ethical foundation for any socio-political change and subsequently acts as a successor to the religious style that develops in Acehnese society. During the conflict, the role of the Ulama was not very significant due to the political constellation that occurred. The Ulama have been polarized and their influences are weakening. But institutionally, the role of the Ulama has not changed and is always present in the people of Aceh to participate in initiating peace.

After the conflict, the position of the Ulama was strengthened again, and in the process of reconciliation, the role of the Ulama in Aceh was related to four things. 1), Knowledge transmission. 2) As a decision-maker, regarding Islamic law. 3) As a mediator. 4) The role of culture, as an agent who is actively involved in resolving disputes that occur in the people of Aceh.

The involvement of Ulama in the post-peace reconciliation process is a necessity. The knowledge of the Ulama which has been recognized by the people of Aceh and the strength of the Dayah network is a great potential for the success of the current reconciliation project.

The combination of religious teachings and local wisdom that has been practiced by Ulama in solving various cases in the Acehnese society is an alternative that must be taken by the government in reconciliation work. If the Ulama are engaged and are directly involved in the reconciliation process initiated by the government through the TRC-Aceh, it is highly likely that the post-conflict reconciliation project will be successful. The Ulama together with its Dayah 
network and alumni scattered throughout Aceh became a large capital to heal the wounds caused by the conflict that have occurred in the people of Aceh.

\section{Acknowledgement}

The authors would like to thank the Ministry of Religion of the Republic of Indonesia for funding support and facilities for making this research success through Interdisciplinary Research Grant (984/UN.08/B.I/KP.01.2/06/2019), awarded by the Directorate General of Islamic Education, the Ministry of Religion of the Republic of Indonesia. The authors also wish to thank all informants who have provided help and information during this research conducted.

\section{References}

Amiruddin, M. H. (2003). Ulama dayah: Pengawal agama masyarakat Aceh. Lhokseumawe: Nadiya Foundation.

Amiruddin, M. H. (2008). Aceh dan Serambi Mekkah. Banda Aceh: Yayasan PENA.

Amiruddin, M. H. (2017). Ulama Dayah Pengawal Masyarakat Aceh. Banda Aceh: LSAMA.

Aspinall, E. (2007). From Islamism to Nationalism in Aceh, Indonesia. Nations and Nationalism, 13(2), 245-263.

Azra, A. (1998). Jaringan ulama: Timur Tengah dan kepulauan Nusantara abad XVII E XVIII: akar pembaruan Islam Indonesia. Bandung: Mizan.

Bardan, I. (2008). Resolusi Konflik dalam Islam: Kajian Normatif dan Historis Perspektif Ulama Dayah. Banda Aceh: The Aceh Institute.

Barter, S. J. (2008). Ulama, the State, E War: Islam-State Relations in the Aceh Conflict. Washington: University of Washington.

Burhanuddin, J. (2012). Ulama \& kekuasaan: Pergumulan elite Muslim dalam sejarah Indonesia. Bandung: Mizan.

Bustamam-Ahmad, K., \& Amiruddin, M. H. (2013). Ulama, separatisme, dan radikalisme di Aceh. Yogyakarta: Penerbit Kaukaba.

Faisal, S. (1989). Format-format penelitian sosial: dasar-dasar dan aplikasi. Jakarta: Rajawali Pers.

Ferdiansyah, M. (2015). Dasar Penelitian Kualitatif. Bogor: Herya Media.

Firdaus, F. (2019). Peran Organisasi Teungku Dayah Dalam Pelaksanaan Syariat Islam di Aceh (Doctoral dissertation). Medan: State Islamic University of North Sumatra.

Hadi, A. (2004). Islam and state in Sumatra: A study of seventeenth-century Aceh. Leiden: Brill.

Ibrahim, I. (2003). Posisi Agama dalam Konflik Aceh. In Akar Konflik Manusia. Banda Aceh: Arraniry Press.

Ichwan, M. N. (2011). Official Ulema and the Politics of Re-Islamization: The Majelis Permusyawaratan Ulama, Sharī'atization and Contested Authority in Post-New Order Aceh. Journal of Islamic Studies, 22(2), 183-214.

Kartodirdjo, S. (1981). Elite dalam perspektif sejarah. Jakarta: LP3ES.

Kasim, F. M., \& Nurdin, A. (2015). Sosiologi Konflik: Sosiologi Masyarakat Aceh. Lhokseumawe: Malikussaleh University Press.

Kingsbury, D. (2006). Peace in Aceh: A personal account of the Helsinki peace process. Jakarta: Equinox.

Koentjaraningrat, K. (1991). Metode-metode penelitian masyarakat. Jakarta: Gramedia Pustaka Utama. 
Ilham, I., \& Abdullah, I. (2015). Aceh dalam Kuasa Awak Nanggroe (Studi Kemunculan Elit Baru dari Kalangan Mantan Pejuang GAM pasca Penandatanganan Nota Kesepahaman MoU Helsinki) (Master's Thesis). Yogyakarta: Gadjah Mada University.

Muhammad, R. A. (2003). Revitalisasi Syari'at Islam di Aceh: Problem, Solusi, dan Implementasi. Jakarta: Logos Wacana Ilmu.

Neuman, W. L. (2000). Social Research Methods: Qualitative and Quantitative Approaches. Boston: Allyn \& Bacon.

Nirzalin, N. (2018). Jaringan Ideologi Keilmuan dan Modal Politik Teungku Dayah di Aceh. SUBSTANTIA, 20(2), 185-195.

Sabil, J. (2012). Peran Ulama dalam Taqnin di Aceh. Jurnal Transformasi Administrasi, 2(01), 199217.

Saby, Y. (1995). Islam and Social Change: The Role of the Ulama in Acehnese Society (Doctoral Dissertation). Philadelphia: Temple University.

Saby, Y. (2001). The Ulama in Aceh: A Brief Historical Survey. Studia Islamika, 8(1).

Sufyan, M. S. (2016). Peranan Majelis Permusyawaratan Ulama dalam sistem pemerintahan Aceh (Doctoral Dissertation). Kuala Lumpur: University of Malaya.

Sulaiman, M. I. (2000). Aceh Merdeka: Ideologi, Kepemimpinan, dan Gerakan. Jakarta: Pustaka AlKausar.

Yeoh, S. C. (1994). Umara-Ulama-Ummah Relations and Pesantrens in Aceh Province, Indonesia: A Study of the Challenges to the Authority of a Traditionalits Kiyai (Doctoral Dissertation). Washington: University of Washington.

\section{About the Authors}

1. Muhammad Sahlan, obtained his Master Degree in Peace and Conflict Resolution Studies from Gadjah Mada University, Indonesia, in 2006. The author is an Assistant Professor at the Department of Sociology of Religion, Faculty of Usuluddin and Philosophy, Ar-Raniry State Islamic University of Banda Aceh, Indonesia.

E-Mail: sahlan.hanafiah@gmail.com

2. Suci Fajarni, obtained her Master Degree in Sociology from Gadjah Mada University, Indonesia, in 2016. The author is an Assistant Professor at the Department of Sociology of Religion, Faculty of Usuluddin and Philosophy, Ar-Raniry State Islamic University of Banda Aceh, Indonesia.

E-Mail: sfajarni@gmail.com

3. Siti Ikramatoun, obtained her Master Degree in Sociology from University of Indonesia, in 2015. The author is an Assistant Professor at the Department of Sociology, Faculty of Social and Political Sciences, Syiah Kuala University, Indonesia.

E-Mail: siti.ikramatoun@unsyiah.ac.id 
4. Ade Ikhsan Kamil, obtained his Master Degree from Gadjah Mada University, Indonesia, in 2016. The author is an Assistant Professor at the Department of Anthropology, Faculty of Social and Political Sciences, Malikussaleh University, Indonesia.

E-Mail: ade.ikhsan.kamil@unimal.ac.id

5. Iromi Ilham, obtained his Master Degree from Gadjah Mada University, Indonesia, in 2016. The author is an Assistant Professor at the Department of Anthropology, Faculty of Social and Political Sciences, Malikussaleh University, Indonesia.

E-Mail: iromi.ilham@unimal.ac.id

Copyright (C) 2019. Owned by Author(s), published by Society. This is an open access article under CC-BY-NC-SA license. 